\title{
The Eldritch Storyteller: Revisiting Edgar Allan Poe's inimitable oeuvre
}

\author{
Kevin George
}

Department of English, K.E College, M.G University, Kottayam, India

\begin{abstract}
Allan Poe's standalone fame rests to an extent, on the fact that he was a conjurer of macabre tales of 'mystery, supernatural and suspense' unrivalled and inimitable even today. His stories and poems weren't influenced by personal factors like unrequited love (except maybe 'The Raven'), bereavement or tragic events of that sort. He wrote for the sake of writing and usually out of an uncanny impulse, unlike Mary Shelley who wrote her magnum opus 'Frankenstein' based on events from her own life. Poe's preoccupation with the occult gravitated towards the themes of death and decay and a contemplation of the same in a manner quite unexplored by writers of this genre. The theme of madness/ insanity was never dealt more tactfully in the history of horror genre. Poe's predilection for the macabre enabled him to explore uncharted arenas. His 'Metzengerstein', for example, is regarded as the first story to have 'metempsychosis' as its central theme. His poems were also not different in its preoccupation with the enigmatic, supernatural and the Gothic.
\end{abstract}

Keywords-Eldritch, Uncanny, The Gothic, The Raven, Schadenfreude.

\section{INTRODUCTION}

One of the most prominent themes in Poe's work is death and the associated process of decay, a hackneyed theme in most, if not all gothic stories. The ominous tone of the narrator is often discomfiting to readers quite unaccustomed to his style. 'The facts in the case of Mr.Valdemar', for example deals with an experiment that goes awry, when the narrator Mr.P ( who could be Poe himself) makes an attempt to arrest the death of the eponymous Valdemar and tries to bring him back to life months later. The body of his friend disintegrates into a putrefying liquid, an act which instils horror in Mr.P's mind (or our minds). Poe's 'A premature Burial', a story dealing with a similar theme is a first-hand account of being buried alive. Poe also cites different instances where the victims had to go through similar harrowing experiences, evoking a sense of premonition in the minds of his readers. According to Poe, this unearthly experience is the most terrifying ordeal because it leaves the victim in a stifling position combined with the fear of an impending death and claustrophobia. Poe narrates the story in a very convincing manner and in a way, becomes a central character, a motif in his works. The eldritch experience of 'life in death' was one of his greatest inventions, something unparalleled in the history of horror fiction, even today. 'The Masque of the Red Death' has as its central theme the ineluctability of death, the titular plague 'Red Death'. This tale was purportedly inspired by the bubonic plague, which ravaged London in the $14^{\text {th }}$ century leaving a quarter of its population dead. The eponymous
'Red Death' is personified as an unscrupulous murderer, who evokes fear in the minds of the populace. But, Poe has imputed to it a disinterested demeanour, exemplified in its choice of victims; including the rich and the poor, young and the old etc. The desperate attempts to evade the 'Red Death' by confining himself to the interiors of the castle end in futility for the crown prince Prospero. The 'Red Death' arrives as an unwelcomed guest to the masque and kills Prospero and his noble friends as soon as he is unmasked. Poe was perhaps trying to tell the world how infinitesimal and pointless its efforts were in evading something as powerful and ineluctable as death. The rooms themselves signify the various stages in one's life. The guests move from one room to the other unwittingly crossing the frontiers of life and death. 'The black and red room' which signifies death is left deserted by the guests in the beginning. It is at this particular moment that the ghoulishly dressed guest enters the masque, attracting a lot of attention for his flagrantly discourteous attire. The spots of blood on the face and the long cloak undoubtedly symbolize the eponymous plague and Prospero is indignant and perturbed like never before. The prince is goaded by the strange figure to enter the dreaded room where he meets his adversary- Death himself. Poe's stories are subtle, unpredictable and enigmatic as exemplified by this tale.

Madness is yet another theme deftly dealt by Poe. The madness of the protagonist is usually a reflection of Poe's eccentric (or should I say demented) mind and its turbulence is evocative of the Gothic when it is coupled 
with dark alleys, catacombs and mansions on the verge of destruction. The madness of the central character is usually an outcome of some unfortunate past, like in his 'The cask of Amontillado', 'The Tell-Tale Heart' 'The Raven' and many other works. The unreliable narrator in 'The cask of Amontillado', for example is a man endowed with preternatural intellect in one sense, if we consider how nefariously he covers up Fortunato's murder. At the beginning of the story, he vaguely hints at the reason why he had decided to take the drastic step. Fortunato dressed as a clown is in fact ludicrous for the kind of naiveté he evinces. He is lead through the darkest chambers of the Montresor catacombs, without a hint of the impending danger. Poe has made effective use of irony throughout the story and most of Montresor's replies have a double meaning, which adds to its uncanny beauty. The sinister tone of the narrator at some points evokes horripilation, a true characteristic of the Gothic narrative. A series of conversations between the two gives the reader an idea of what is yet to come, mainly Fortunato's impending death. Poe opens a portal into the mind of the psychotic killer for his readers and expects them to relish in his schadenfreude. Fortunato's innocence might evoke sympathy in the minds of some readers, but his inebriated condition and ingenuous disposition veers him toward an irredeemable fate. In a bloodcurdling climax, he is buried alive inside the masonic chamber and all we hear are doleful shrieks of a man, gaining consciousness only to realize that he is going to die a gruesome death. The event is narrated through a parchment years later, most probably through a confidant, giving us a glimpse of the lunatic mind, which conjured up perhaps, the most nefarious murder of the period. The narrator of 'The Tell-Tale Heart' suffers from a similar disorder as he finds himself unable to convince the readers of his sanity. He starts by giving evidence for the same, an attempt in vain as it brings him under the reader's suspicion even more. The justifications for committing the gruesome, motiveless murder are absurd. The narrator who is purportedly perturbed by the old man's stare decides to silence him. He dismembers the body and surreptitiously hides it under his floor bed. When the policemen arrive, he starts panicking after hearing strange palpitations, which forces him to confess his wellplanned murder. It is undoubtedly his own sanity which comes under the reader's suspicion. The beating of the old man's heart is nothing but a figment of his own imagination. A similar tale is Allan Poe's 'The Black Cat', in which the murderer-narrator finds himself in a helpless position. But, his insanity is rather enforced by alcohol and to an extent by his own deluded mind. The narrator regains his sanity after years of incarceration and the tale is more of a confession. He recounts how he was instigated into committing two murders- that of his cat and his wife. Poe's narration is quite unique as he tries to convince his readers that instability of mind could be induced as much as it's innate. The narrator, on one of his inebriated evenings finds the very sight of his favourite cat disturbing and on an impulse kills it after subjecting it to a series of torturous experiments. Days later, he finds an identical cat roaming around his locale and he is reminded of his crime. The readers will never fathom the mystery behind its reappearance, whether it is the same 'Black Cat' or its ghost seeking vengeance. The disturbed narrator (as he recounts) decides to kill it secretly and upon his wife's interference, hacks her to death instead. Poe is a brilliant storyteller as he wanted the readers to know that not all murders were motivated by revenge, but out of unprecedented fits of madness. While trying to cover up the corpse, he forgets about the cat and later, when the investigation is on, a strange cry from the wall forces them to unplaster the wall, revealing the mangled corpse with the cat ensconced on the head. We never really get to know how the cat got inside the wall. It's a mystery that Poe leaves to our imagination.

Allan Poe's Magnum Opus 'The Raven' could be regarded as the acme of his imaginative prowess. The introduction of a callous bird to instil a sense of portentous feeling is tremendous. The bird is initially presented as a creature seeking refuge inside the protagonist's chamber. Guy De Veres (the woebegone narrator) opens the chamber window after hearing a series of tapping. This 'tapping' could be his imagination and the readers ought to question his sanity. It's evident that the death of his beloved 'Lenore' has left him in a miserable position. The uncanny raven replies 'Nevermore' to the protagonist's queries, at first leading him to think of its vocabulary as restricted to that particular word. He imagines the raven to have picked up the word 'Nevermore' from an unhappy master and continues asking more personal questions, only with a nefarious intent. This endless questioning is rather masochistic in nature as Poe would have wanted us to know. The bird replies 'Nevermore' to everything that he says. When he enquires about his rendezvous with Lenore in Gilead, the ominous bird utters the same piercing word. In the end, Poe wanted us to believe that the bird would never leave his soul alone, a premonition of his eternal damnation. Poe's brilliance comes to light when we consider the lingering effect of the poem and the powerful images it evoke in the minds of the readers, for example that of the bird ensconced on the bust of Pallas. The bust of Pallas symbolizes wisdom, as Athena is regarded as the goddess of wisdom and art. The raven on top of it conveys 
a rather different idea; the overwhelming power of superstition over reason or perhaps, the vulnerability of the mind (sanity), as in the case of this bereaved lover. Poe's mind was evidently prescient and his obsession with the supernatural (or the uncanny) doesn't surprise the reader. One must also note that the setting is purely gothic, with the inclement weather (the tempestuous night) outside adding more vigour to its strangeness. The milieu of his other notable poems like 'Annabelle Lee' and 'Ulalume' are also reminiscent of the same. The themes of the poems are also similar, as in his 'Ulalume' and 'Annabelle Lee', where the bereaved lovers mourn the death of their loved ones and are haunted by the memories of the same. The setting itself is gothic in 'Annabelle Lee'. 'The city by the sea' has an uncanny aura as it is located in a remote place, inaccessible to mortals. The horrendous image of the 'sepulchral city', where everything comes to decay instils in the readers a 'gothic chill', ineffable but overwhelming at the same time. Poe exploits the gothic idea of the doppelganger in his 'The Fall of The House of Usher'. The twins, Roderick and Madeline and the incestuous legacy of the Usher family hints not only at an eerie connection between the siblings, but also at the enigmatic nature of the happenings inside the mansion. Both are in a way, inseparable as evident from its climax, which continues to surprise readers even today. The unanticipated death of Roderick Usher in the end exemplifies the ineluctability of a reunion (in death). The claustrophobic chambers of the mansion, a persisting sickness in the family and the dreary landscape are also evocative of the gothic, especially the part where the narrator and the host decide to bury Madeline in one of its sepulchral vaults. The occult aura surrounding the mansion becomes clearer as the story progresses. The mansion is just as fragile as its inhabitants. The mildewed and tottering mansion reminds one of the moribund Madeline and the valetudinarian Roderick. The premonitory dream of Usher becomes a reality, when Madeline's ghost appears out of nowhere and kills him, to the horror of the narrator (or, perhaps the reader). The scene culminates in a blood-curdling climax with the collapse of the mansion in the end, leaving a sensation of a lingering frisson in the minds of the readers.

\section{CONCLUSION}

Poe's works were inimitable not because his entire collection of short stories or his poetry dealt with the Gothic. It was Poe's innovative style of interpolating the supernatural into quotidian events, thereby giving it a hue of the uncanny that merits mention here. His notion of the 'supernatural' was quite different from the archetypal ones. In most cases, the readers are left to ponder over the nuances or the subtleties of his tales/ poems as none of his works reveal themselves to the readers on a first reading. The black cat from his eponymous tale, for example is an enigma. On a first reading, it gives the reader some hints as to the revelation of the gruesome murder, only to alter everything when it is read again. Did a phenomenon similar to 'metempsychosis' take place? Or did the truth come out from the narrator's own tongue after a series of harrowing hallucinations? This is why Poe's style is unique. Novelty never really dies after a single reading. And that's why his immortal fame rests on an empyrean pedestal, rivalled by none.

\section{REFERENCES}

[1] Poe, E. A. (2014). The complete tales \& poems of Edgar Allan Poe. Knickerbocker Classics.

[2] Poe, E. A. (1984). Poetry and tales (Vol. 19). Library of America.

[3] Shelley, M. (2012). frankenstein. Broadview Press. 